\title{
Ebb and Flow in the Journey of Real Estate Sector in India
}

\author{
Effulgence \\ Vol. 18, No. 2 \\ July - December, 2020 \\ Rukmini Devi Institute of Advanced Studies \\ E-mail : effulgence@rdias.ac.in, Website : www.rdias.ac.in \\ http://effulgence.rdias.ac.in/user/default.aspx \\ https://dx.doi.org/10.33601/effulgence.rdias/v18/i2/2020/44-57
}

\section{Dr. Sakshi Vasudeva ${ }^{1}$}

\begin{abstract}
Investments in real estate sector in India have seen many ups and downs in India. The investment returns are less volatile as compared to other investments but it is less liquid and involves huge initial costs. In spite of all odds, the investment has an additional advantage of satisfaction of emotional and social gratification of being owner of an immovable property. The purpose of the current study was to review some of the research work on real estate sector investments and to narrate the journey of the sector in India by discussing some important measures taken by the Govt. of India at various times and to evaluate the current state of property sector in India and the movement of HPI since 2010-11 till the end of 2018-19 and first two quarters of 201920. The study also calculated the relation of house price index with some of the macro-economic variables from 2010-11 till the end of 2018-19. Through review of various studies, it is found that investment in real estate sector is a complex one and various economic and non-economic factors (psychological factors) affect the real estate investment. Studies on boom where in the prices and demand were at the highest levels in the real estate sector indicate that improvement in the macro economic conditions also lead to improvement in the investment climate of real estate sector. Government of India has taken favorable steps by providing various tax incentives and making home loans more attractive and affordable; this all have started to bring momentum in the growth of real estate sector investment, but the current pandemic outbreak of Covid 19 have hit the whole economy including real estate sector. It could be temporary phase only if war over Covid 19 is won at the earliest.
\end{abstract}

Keywords: Real Estate Sector Investment, Liquid Investment, Psychological Factors, House Price Index, Macro Economic Variables, Home Loans, and Tax Incentives.

\section{INTRODUCTION}

$\mathrm{I}_{\mathrm{r}}^{\mathrm{n}}$ nvestment in real estate holds special significance for many especially in India where people have desire to own a home and thus investors feel an advantage of social status of landlord/owner of immovable property, while at the same time there is possibility of capital appreciation. Though in recent past, investments in real estate have not been so lucrative because of stagnant real estate prices. Investors found it difficult to liquidate their real

1. Assistant Professor, Department of Commerce, Dr. Bhim Rao Ambedkar College, University of Delhi 
estate investments because of failure of builders to meet time deadlines in handing over possession of residential and commercial projects. Real estate investment involves the purchase of property which means ownership, rental income by letting out the property and sale of real estate sector investments (both commercial and residential holdings), thus pocket capital gains. It also includes investment in real estate investment trusts.

Investment in Real Estate has some advantages such as feeling of being landlord; owing an asset which can generate regular rental income; tax benefits because of exemptions available on purchase of real estate and home loan interest and principal repayments; possibility of up to $80 \%$ of mortgage finance from financial institutions such as banks; less volatility as compared to many other investment options such as stocks ${ }^{182}$. Investment in real estate has some disadvantages also such as high purchase costs, high initial costs such as commission to broker and property registration costs. Then, there are risks of buying an unapproved property or delayed delivery in case of investment in under construction properties. There are regular expenses in the form of maintenance cost of the building/apartment, insurance charges, local property taxes, and interest outgo on property loans, risks of destruction/damage to property, problems of illegal occupation by tenants or others. It is one of the illiquid investments as it not easy to sell the property if there is an immediate cash requirement ${ }^{2}$. The current paper is an attempt to narrate some of the important research findings across the globe for real estate sector investments; to discuss various measures taken by Indian Government to improve the sector and present state of real estate sector investments in India.

\section{Literature Review}

\section{The following papers have been studied and their findings are discussed as below: \\ General Issues related to Real Estate Investment}

MISHRA, A. (2018) compared real estate to Gold and concluded that real estate has some advantages over Gold such as regular rental income, whereas investment in Gold is flexible and comparatively more liquid investment. A study conducted by Case, K. E., \& Shiller, R. J. in 1988 also shared the similar belief that Real estate sector had few positives in comparison to gold or even stocks in normal circumstances. Firstenberg, P. M., Ross, S. A., and Zisler, R. C. who conducted study in 1988 pointed out an important lapse on the part of real estate investors of 'investing comparatively less amounts and too little attention to real estate diversification'.

In 2006, Joshi, H; who was the Ex- Director in the Monetary Policy Department of RBI emphasized in his paper that the 'house prices in India were having a higher correlation with the changes in the interest rates and expansion/contraction in real estate sector finance (loans) as compared to increase or decrease in real income'. Sahni, M. S., Bank, A. A., \& Point, N. (2008) also discussed the various factors affecting real estate in India.

\section{Behavioural Biases related to Real Estate Investments}

Kishore, R. (2004) discussed behavioral factors to understand the boom in real estate sector in Australia and found that 'speculation and investor irrationality' which he termed as "herd mentality", caused prices to rise exorbitantly; the appreciation was not real and to some extent, the high prices were

1. Wikipedia Source "Real estate investing" downloaded from https://en.wikipedia.org/wiki/Real_estate_investing (retrieved 10 March, 2020).

2. Murdock Edgar, Christy. "The 5 Pros and 3 Cons of Real Estate Investing". Available at https://learn.roofstock.com/blog/pros-and-cons-real-estate-investing retrieved from Wikipedia Source "Real estate investing" https://en.wikipedia.org/wiki/Real_estate_investing (10 March, 2020). 
felt because the market overreacted to expected changes in the interest rates in the future. Other studies that tested the application of efficient market hypothesis to property market through empirical work include Gou, G. (1984); Case, K. E., and Shiller, R. J. (1988) \& Brown, G., \& Chau, K. (1997). These studies found that property market is so complex that none of the efficient market hypothesis theories can explain it fully; therefore both rational and psychological factors are relevant in real estate sector. Waweru, N.M., Mwangi, G.G. \& Parkinson, J.M. (2014) conducted a study using behavioural finance theories.by conducting the opinion survey of real estate agents of Kenya to find the decision pattern \& basis of property investors there and they found that behavioural factors of "anchoring"; "representativeness" and "availability bias" influenced property investment decision making (p.19).

Pandey, R. and Jessica, V. M. (2018) found that the behavioral biases (heuristics) influenced the investments in the real estate in the Indian scenario. Pandey, R., \& Jessica, V. M. (2019) in another study found that behavioural biases/psychological factors (heuristics) influenced decisions to invest in the real estate \& satisfaction level of investors had a significant mediating effect between behavioural biases and investment decisions.

\section{Study on Bubbles in the Housing Sector}

Herring, R., \& Wachter, S. (2003) “Real estate bubbles are also caused by bank behavior" (p.218). Another study by Pandey, R., \& Jessica, V. M. (2019) was conducted to understand the effect of the 2008 financial crisis across the globe on housing/property market in India. The study found that changes in the monetary policy such as bank rates, credit flow impacted the housing sector scenario in India. Vishwakarma, V. K., \& Paskelian, O. G. (2012) used a "speculative bubble model" of studies of Van Norden S. \& Schaller, H. (1993) and some other econometric methods and found that there was no effect of global economic slowdown as in 2007-2008 on real estate sector in India. There were 2 studies that are of Abraham, J. M., \& Hendershott, P. H. in 1994 \& of Case, K. E., \& Shiller, R. J. (2003) that found that speculative bubble had a presence in the housing market of United States. Clayton, J (1997) studied bubbles in real estate market of Canada. Study by Levin, E. J., \& Wright, R. E. (1997) found that prices in UK housing sector were influenced by economic fundamentals as well as speculation in the housing market. Qin, X. (2005) found that there is presence of bubbles in both Seoul and Hong Kong markets. Joshi, H. (2006) studied bubbles in the real estate in India on the lines of model evolved by Van Norden S. (1996), and Van Norden S. and Schaller, H. (1999) and found that the monetary policy changes such as interest rates and credit expansion had a significant role in influencing housing prices and also found existence of bubble behavior at the end of 2007 till the end of 2010.

\section{Research Methodology}

The current paper uses "descriptive methodology" to discuss the current scenario of real estate in Indian Market and to narrate various important measures taken by the Government from time to time since first five year plan till the last five year plan and in the immediate past to nurture and promote real estate. It also manifests the ups and downs (ebb and flow) in the real estate since 2010-11 till the end of 2018-19 using the data available from RBI website on housing price index (quarterly data); bank rates, GDP, Per Capita NNI and Gross Savings as \% of GDP. There was a time when real estate prices were at the highest levels but last 10 years, we witnessed stable prices and sometimes negative growth. Average of Quarterly data (Year Wise) has been used to calculate relation with macroeconomic indicators as discussed above using correlation coefficients. Graphs have been used to depict movement of HPI on all India level and for 10 major cities in India. The data has also been analyzed using measures of averages and standard deviation to study the ebb and flow. In addition to calculating for overall period, the time period is divided into two parts 
using separate calculations for the period from 201011 to quarter ending 2015-16 and then from 2016-17 till 2018-19. This is done as small momentum could be seen in the sector from 2016-17.

\section{Objectives of the Study}

1. To discuss the various measures taken by the Govt. of India at various times in the context of real estate sector in the country.

2. To critically evaluate the current situation of real estate sector (property market) in India and the ebb and flow in HPI taking 2010-11 as base year till the end of 2018-19 and first two quarters of 2019-20.

3. To find out the relation of house price index as released by RBI with some of the macroeconomic variables from 2010-11 till the end of 2018-19.

\section{Measures Taken by Indian Government in the context of Real Estate Sector in India}

The Government of India took various measures from time to time to promote housing sector, predominantly in urban areas. In the 1950s, there was requirement of urban planning and promote housing sector, that's why Policy of Urban Development and Housing in India came much early, i.e., in 1950s. After independence, the Government took various initiatives to provide shelter to all. From time to time, the Government took various measures to provide housing in the both urban and rural areas. First Five Year Plan (1951-56) focused primarily on promoting institutional support to the housing sector and providing house to the most vulnerable sections of the society. In the Second Plan (1956-61), the scope of "Industrial Housing Scheme" was broadened to cover all kinds of industrial workers. Various Schemes for housing in the rural sector; clearance of Slums \& provide housing to the sweepers were introduced to target specific sections of the society. During Third Plan (1961-66), needs of the economically weaker groups were largely focused while chalking out policies for the housing sector. The Fourth Plan (1969-74) mainly focused on creation of smaller townships to avoid congestion in large cities and to prevent the grooming of slums. HUDCO (Housing \& Urban Development Corporation) was incorporated in April, 1970. Earlier, it was set up as a private limited company under the complete ownership of the Government to promote the provision of housing finance and development of urban infrastructure. The Fifth Plan (1974-79) also focused on promoting smaller towns in new urban centers. The Urban Land (Ceiling \& Regulation) Act was enacted in 1976. The purpose was to discourage concentration of land in urban areas to provide housing for both middle and economically weaker income groups. The Sixth Plan (1980-85) also focused to provide shelter to the poor. During the Seventh Plan (1985-90), responsibility for housing sector development from the Government Sector was also assigned to the private sector. The National Housing Bank (NHB) was set under the patronage of RBI on 9th July, 1988. During 1988, National Housing Policy (NHP) was announced. The purpose of NHB was to promote housing finance institutions at all levels and to strengthen other institutional support connected therewith. The Eighth Plan (1992-97) mainly focused on urban sector and also its role in the housing market in India. The Housing and Habitat Policy (1988) targeted to ensure "shelter for all" and recognize it as basic necessity like food and clothing. The main objective of the policy was to work out strong public-private partnership (PPP model) to tackle situation and the Government's role was recognized more as a promoter and enabler by offering fiscal concessions and bringing various legal and regulatory reforms. Since then private investment in housing sector increased manifold and many big real estate developers entered the real estate market. During Ninth (1997-2002) and Tenth Five year plan (2002-2007), the efforts were made to provide housing in urban areas and shelter for the poor and the most vulnerable sections of the society. Urban Land (Ceiling and Regulation) Act, 1976 [Repeal Act, 1999] is a significant step. After repeal by the Centre, 
various state governments also repealed their state laws. The Government made some changes in the legislative sector and allowed some fiscal concessions to promote development of housing sector. The National Common Minimum Program (NCMP) which is functioning since 2004 envisioned to provide housing to the economically weaker sections in rural areas. Tenth Plan made special provision of free housing for SC/ST families under some conditions and for other BPL families under subsidized loans structure. The Eleventh Five Year Plan (2007-2012) stressed more on the need of improved housing in urban areas and also in urban slums and to promote new townships. The Bharat Nirman Program and Indira Awas Yojana Scheme also targeted to construct houses and the focus of the schemes has always been on the poorest of the poor. 12th five year plan (2012-2017) which was the last plan also had the same objectives. The NHB Act was amended to facilitate easy foreclosure. During the early years, initiatives were taken mostly by the Government, but in the recent years, private real estate developers helped to achieve significant growth though mostly in urban and semi- urban areas $^{3}$. The Government of India took various steps to give boost to the housing sector during last few years. In March 2005, the Government of India allowed 100\% FDI in the construction sector and other development projects ${ }^{4}$.

The RBI in 2013 instructed banks not to release the funds as a lump sum but to release sanctioned loans of buyers according to various milestones in construction $^{5}$. Real Estate (Regulation and Development) Act, 2016 (RERA) which is one of the landmark legislation came into existence in May, 2016 to improve the sector by giving buyers an advantage of transparency and making builders accountable to deliver according to promised specifications.

NDA government in the recent past introduced various support measures such as setting up of a Rs 25,000 crore of investment fund (alternative fund) to support funding of undelivered economical housing projects $^{6}$; rationalizing of GST rates ${ }^{7 \& 8}$. Taxpayers are given additional tax reliefs in the form of interest deduction for affordable homes upto Rs 45 lakh taken till March 31, 2020 $0^{788}$. Non-banking financial companies (NBFCs) and banks are also allowed to increase their exposure to the real estate sector by supporting in terms of partial credit guarantee scheme to increase their confidence ${ }^{8}$.

\section{ANALYSIS TO STUDY THE CURRENT STATE OF REAL ESTATE (PROPERTY) SECTOR INVESTMENT IN INDIA}

Commercial real estate sector has witnessed upsurge in India. Report by IBEF (India Brand Equity Foundation) on Real estate mentioned that 'It is expected that real estate sector in India would

3. National Housing Bank (NHB)- 'Urban Housing under five year plans'. Retrieved from https://test.nhb.org.in/Urban_Housing/5year_plan.php (Accessed on 12 march, 2020)

4. FDI in Construction Industry (2005, March 12) The Times of India. 12 March 2005. from https://timesofindia.indiatimes.com/hyderabad/FDI-in-construction-industry/articleshow/1049608.cms (Retrieved 5 Jnauary, 2020))

5. Tanvir A; Siddiqui (2014, October, 11). "RBI cautions co-op banks against lump-sum disbursal of loans to builders". The Indian Express. (Retrieved 5 January, 2020)

6. Asit Ranjan M. E , Shaswati Das (2019,November 6) “Cabinet clears ₹25,000 crore plan for realty revival" The Live Mint Retrieved from https://www.livemint.com/news/india/govt-approves-rs-10-000-crore-fund-to-help-stalled-housing-projectssitharaman-11573051698810.html (Accessed on 10 Feb, 2020)

7. Sharma, A. (2020, February 1) "What Indian real estate gained in Budget 2020?" The Economic Times Retrieved from https://realty.economictimes.indiatimes.com/news/industry/what-indian-real-estate-gained-in-budget-2020/73838367 (Accessed on 15 March, 2020)

8. MG ARUN (2020, January 28). 'Rebuilding Real Estate India Today Insight', from https://www.indiatoday.in/india-todayinsight/story/rebuilding-real-estate-1640836-2020-01-28 (Retrieved 10 February, 2020). 
achieve magnitude of US $\$ 1$ trillion by 2030 and the sector would be contributing almost 13 per cent in country's GDP by $2025^{9}$.

In 2019, Rs 43,780 crore (i.e; US\$ 6.26 billion) of investments and around US\$ 1 billion of private equity investments was invested in this sector. During the last fifteen years, Indian real estate business has seen a positive turn and is expected to build up from the current US \$ 14 billion to a US \$ 102 billion during next 10 years, It is expected that Grade-A office space absorption would surpass 700 million square feet by 2022 and most of this demand would be from Delhi-NCR region. Sales in the housing sector are expected to increase by 4 per cent on year-on-year basis by 2018 end and there would be increase of around 2.58 lakh units in seven major cities $^{\prime 9 \& 10}$. But for the last few years, real estate sector has not been faring well. According to India Ratings and Research (Ind-Ra) also published in economic times, 'in spite of stimulus package by the Government of India, there is not so positive outlook for real estate sector during 2020-21(April-March), though the rating agency predicted a steady scenario for grade-I residential real estate, commercial offices and property development in the retail sector and its ancillary operations, but it would be negative growth for non-Grade-I players during financial year(2020-21) $)^{11 \& 12}$.

According to the data released by RBI on house price index, the calculation showed that an average growth rate has been 191.50 at the end of the quarter
2018-19 taking 2010-11 as the base. Standard deviation has been 56.43 for the same period indicating lot of variability; that is ebb and flow. M stands for Mumbai, D for Delhi, B for Bangalore, A for Ahmedabad, L for Lucknow, KOL for Kolkata, C for Chennai, J for Jaipur, KA for Kanpur and KOC for Kochi. There has not been good growth from 2010-11 to quarter ending 2015-16 as the average house price index stood at 149.12 but from 2016-17, real estate gathered momentum and average increased to 244.47 (from 2016-17 till 2018-19). (See Table 1 \& 2).

Since, 2015-16, there has been moderate improvement in real estate sector following some positive measures taken by the Government to support the sector. Still, the sector is facing problems as there has been no significant improvement. If we compare the cities, we can see that highest average growth has been witnessed in Delhi followed by Lucknow, then Mumbai. Lowest average growth could be seen in Kanpur and Jaipur (See Table 1\& 2) It can be seen that there has been on an average growth of 23.8, 28.1, 19.3, 27.6,19.8, 18.5, 17.8, 12.6 and 6.5 in the house price index during 2011-12, 2012-13, 2013-14, 2014-15, 2016-17, 2017-18, 2018-19 and 2019-20(Ist 2 quarters only) (See Figure 1)

During 2012-13 and 2014-15, there has been growth of almost $30 \%$ but thereafter the growth was declining and became stagnant around 18/19 percent. (See Figure 1 \& 2 (Graph))

9. India Brand Equity Foundation (IBEF) (2020) "Indian Real Estate-Industry Analysis" downloaded from https://www.ibef.org/archives/industry/indian-real-estate-industry-analysis-reports/indian-real-estate-industry-analysisjanuary-2020 (retrieved 10 March 2020).

10. India Brand Equity Foundation (IBEF) (2019) "Real Estate" from https://www.ibef.org/download/Real-Estate-December2019.pdf (retrieved 10 March 2020)..

11. India Ratings and Research (Ind-Ra) (2019) "Mid-Year FY20 Real Estate Outlook: Liquidity Remains Key for Survival and Growth" from https://www.indiaratings.co.in/PressRelease?pressReleaseID=38960Etitle=Mid-Year-FY20-RealEstate-Outlook\%3A-Liquidity-Remains-Key-for-Survival-and-Growth((Accessed on 10 march, 2020)..

12. Babar, Kailash (2020, February 13). India Ratings maintains negative outlook on real estate for FY21, The Economic Times from https://economictimes.indiatimes.com/industry/services/property-/-cstruction/india-ratings-maintains-negativeoutlook-on-real-estate-forfy21/articleshow/74120863.cms?utm_source=contentofinterestEutm_medium=textEutm_campaign=cppst (Retrieved 2 March, 2020). 
Table 1: House Price Index: Average and Standard Deviation Calculations

\begin{tabular}{|c|c|c|c|c|c|c|c|c|c|c|c|}
\hline Particulars & $\mathbf{M}$ & D & B & $\mathbf{A}$ & L & KOL & $\mathrm{C}$ & $\mathbf{J}$ & KA & $\mathrm{KOc}$ & $\begin{array}{l}\text { All } \\
\text { India }\end{array}$ \\
\hline $\begin{array}{l}\text { Average } \\
\text { From first Quarter 2010-11 to } \\
\text { quarter ending 2018-19 }\end{array}$ & 188.32 & 244.16 & 178.45 & 183.92 & 237.57 & 190.34 & 172.93 & 127.48 & 113.40 & $172.27+$ & 191.50 \\
\hline $\begin{array}{l}\text { Standard } \\
\text { Deviation From first Quarter 2010- } \\
11 \text { to quarter ending 2018-19 }\end{array}$ & 53.82 & 84.05 & 49.51 & 50.88 & 95.78 & 58.72 & 50.52 & 16.90 & 21.17 & 59.22 & 56.43 \\
\hline $\begin{array}{l}\text { Average } \\
\text { From first Quarter 2010-11 to } \\
\text { quarter ending 2015-16 }\end{array}$ & 147.84 & 182.41 & 141.52 & 146.35 & 164.02 & 147.79 & 135.58 & 117.66 & 99.75 & 133.49 & 149.12 \\
\hline $\begin{array}{l}\text { Standard } \\
\text { Deviation From first Quarter 2010- } \\
11 \text { to quarter ending 2015-16 }\end{array}$ & 31.94 & 61.10 & 32.41 & 30.05 & 53.34 & 43.66 & 33.53 & 13.68 & 10.91 & 34.38 & 36.32 \\
\hline $\begin{array}{l}\text { Average } \\
\text { From first Quarter 2016-17 to } \\
\text { quarter ending 2018-19 }\end{array}$ & 238.92 & 321.36 & 224.61 & 230.88 & 329.51 & 243.53 & 219.62 & 139.76 & 130.47 & 220.76 & 244.47 \\
\hline $\begin{array}{l}\text { Standard } \\
\text { Deviation From first Quarter 2016- } \\
17 \text { to quarter ending 2018-19 }\end{array}$ & 23.48 & 17.70 & 17.23 & 25.73 & 39.66 & 14.11 & 18.63 & 11.82 & 18.33 & 46.61 & 19.30 \\
\hline
\end{tabular}

Source: Authors calculations based on housing price index released by RBI

From: RBI "Database on Indian Economy-Time series data on All-India and city-wise HPI" (DBIE) portal retrieved from https://dbie.rbi.org.in/DBIE/dbie.rbi? site=statistics $>$ RealSector $>$ PriceEWages $>$ Quarterly) (Accessed on 01 march, 2020)

Table2: House Price Index Movement City Wise taking 2010-11 as the base year

\begin{tabular}{|l|c|c|c|c|c|c|c|c|c|c|c|}
\hline year & $\begin{array}{l}\text { house } \\
\text { price } \\
\text { index }\end{array}$ & $\mathbf{M}$ & $\mathbf{D}$ & $\mathbf{B}$ & $\mathbf{A}$ & $\mathbf{L}$ & KOL & $\mathbf{C}$ & J & KA & KOC \\
\hline $2010-11$ & 100.0 & 100.0 & 100.0 & 100.0 & 100.0 & 100.0 & 100.0 & 100.0 & 100.0 & 100.0 & 100.0 \\
\hline $2011-12$ & 123.8 & 130.0 & 136.6 & 122.6 & 132.5 & 125.6 & 104.3 & 107.6 & 108.2 & 108.7 & 106.7 \\
\hline $2012-13$ & 151.9 & 153.5 & 193.6 & 138.3 & 148.2 & 157.1 & 154.1 & 128.0 & 119.8 & 101.0 & 121.8 \\
\hline $2013-14$ & 171.2 & 167.8 & 217.7 & 161.6 & 168.9 & 194.2 & 170.8 & 160.5 & 126.2 & 83.6 & 161.1 \\
\hline $2014-15$ & 198.8 & 188.0 & 264.0 & 185.2 & 182.2 & 243.2 & 209.8 & 181.8 & 134.1 & 105.4 & 177.9 \\
\hline $2015-16$ & 218.6 & 206.6 & 299.5 & 203.1 & 198.7 & 274.0 & 225.4 & 198.4 & 132.7 & 110.4 & 174.5 \\
\hline $2016-17$ & 237.0 & 231.3 & 312.0 & 221.0 & 218.7 & 321.8 & 237.3 & 223.2 & 128.1 & 118.1 & 195.6 \\
\hline $2017-18$ & 254.8 & 253.8 & 334.3 & 226.8 & 247.0 & 350.5 & 251.9 & 215.6 & 146.4 & 144.9 & 226.2 \\
\hline $2018-19$ & 267.4 & 263.9 & 339.7 & 247.5 & 259.1 & 371.8 & 259.5 & 241.3 & 151.7 & 148.5 & 286.7 \\
\hline $\begin{array}{l}2019- \\
20 / q 1 \text { ans }\end{array}$ & & & & & & & & & & & \\
q2 & 274.0 & 261.7 & 337.8 & 259.7 & 262.7 & 374.8 & 267.3 & 254.0 & 159.2 & 159.0 & 293.0 \\
\hline
\end{tabular}

Source: Authors calculations based on housing price index released by RBI (average of all quarters has been taken to calculate yearly averages)

RBI "Database on Indian Economy-Time series data on All-India and city-wise HPI" (DBIE) portal retrieved from https://dbie.rbi.org.in/DBIE/dbie.rbi? site=statistics $>$ RealSector $>$ PriceEWages $>$ Quarterly) (Accessed on 01 march, 2020) 


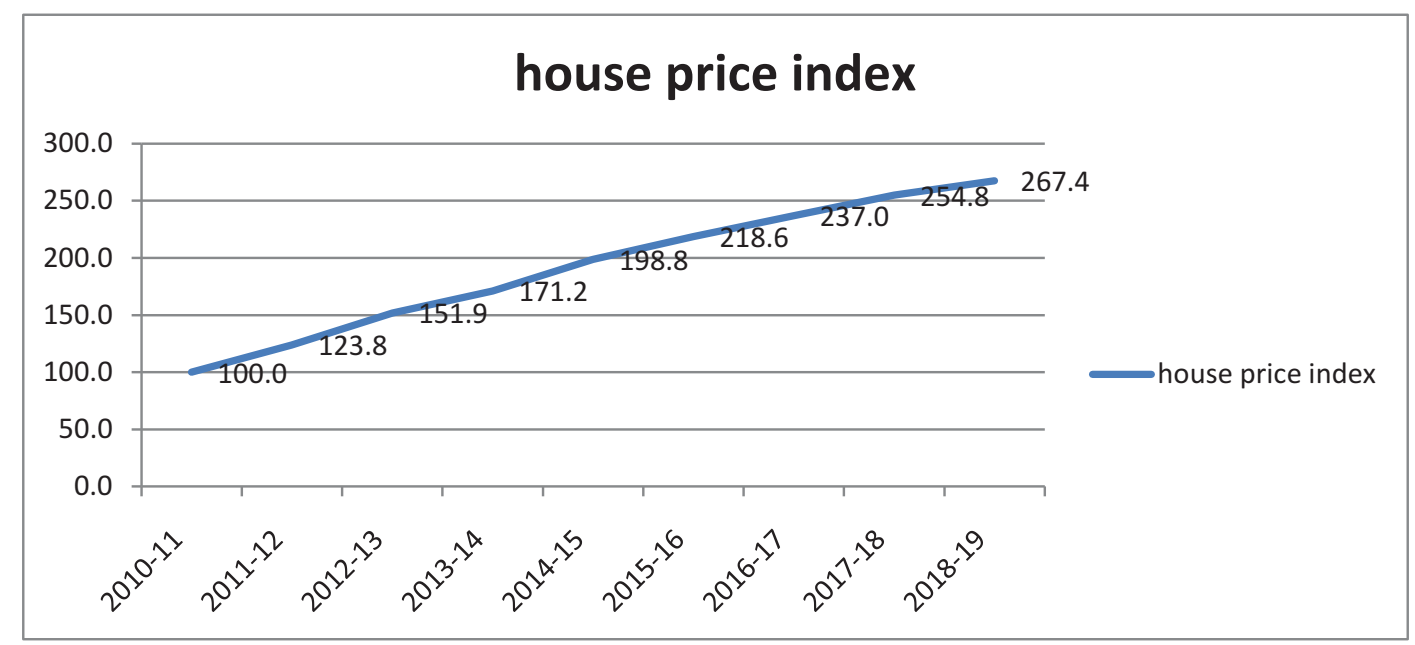

Figure 1: Graph showing Movement of house price index from 2010-11 as base year

Source: Authors calculations based on housing price index released by RBI( average of all quarters has been taken to calculate yearly averages)

From: RBI "Database on Indian Economy-Time series data on All-India and city-wise HPI" (DBIE) portal retrieved from https://dbie.rbi.org.in/DBIE/dbie.rbi?site=statistics > RealSector > PriceEWages > Quarterly) (Accessed on 1 march, 2020)

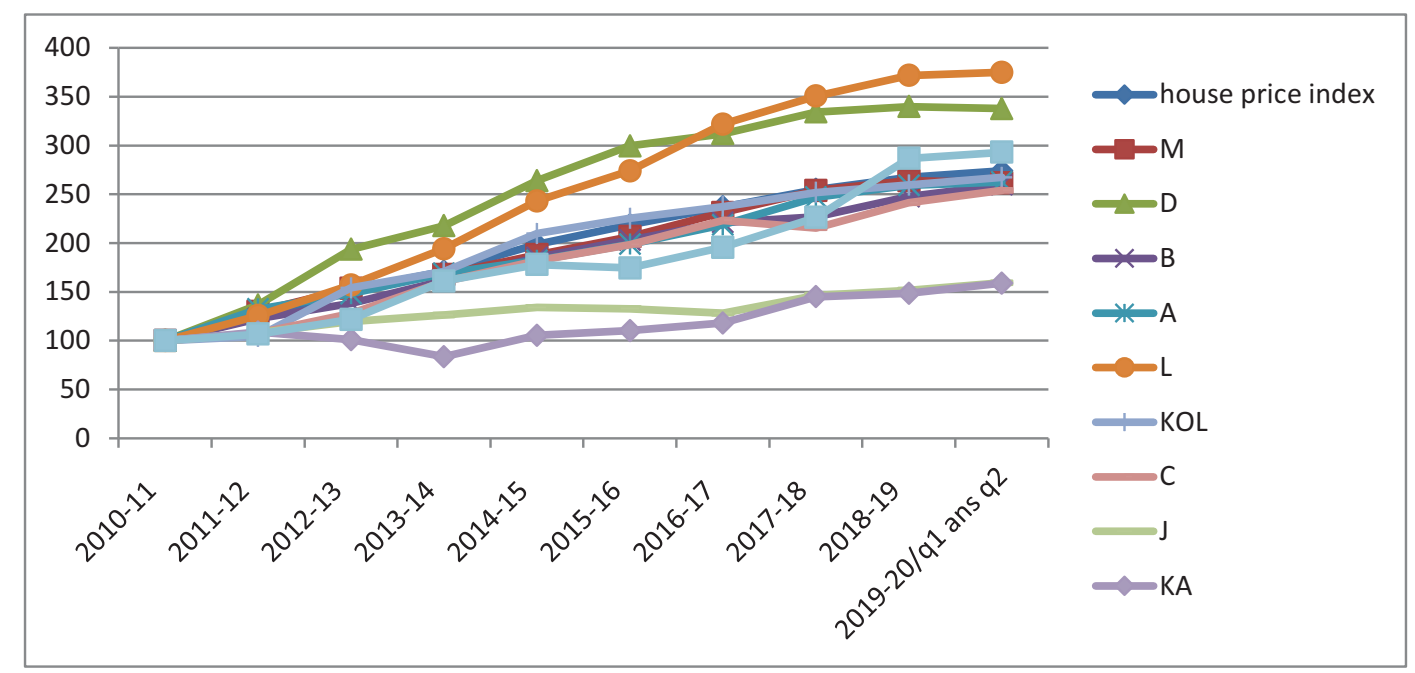

Figure 2: Graph showing Movement of house price index (City Wise) from 2010-11 as base year

Source: Authors calculations based on housing price index released by RBI (average of all quarters has been taken to calculate yearly averages) RBI "Database on Indian Economy-Time series data on All-India and city-wise HPI" (DBIE) portal retrieved from https://dbie.rbi.org.in/DBIE/dbie.rbi? site=statistics $>$ RealSector $>$ Price EWages $>$ Quarterly) (Accessed on 01 march, 2020)

On the basis of reports released by RBI, 'The All-India House Price Index recorded a consecutive increase of 2.5 per cent in Q1 of 2018-19 over Q4 of 2017-18. Large variation was seen if we compare city wise growth, Delhi recorded the maximum rise (5.3 per cent) and Kanpur recorded the highest decline to the tune of negative (-) 2.4 per cent13. Year-on-year basis comparison of all-India quarterly HPI found that there was a growth of 5.3 per 
cent during Q1 (2018-19) and 6.7 per cent in the last quarter (Q4 of 2017-18) and it was 8.7 per cent a year before $^{13}$.

\section{House price index in relation to Macro Economic Indicators}

Residential Real Estate is picking up in India due to easy availability of finance as bank rates, repo rate and reverse repo rate has been continuously declining.

Bank rate was 9.50 as on 13-02-2012, it reduced to 5.40 as on $04-10-2019$, and SLR was reduced from $23 \%$ to $18.25 \%$ as on $11-08-2012$. CRR was reduced from $6 \%$ as on $24-04-2010$ to $6 \%$ as on $27-06-2015$ to $4 \%^{14}$. Retail investors view real estate as an attractive and stable investment option in comparison to many other investment avenues.

Other Driving Forces We can see that house price index has been growing due to increase in GDP, Per Capita NNI and Gross Savings as\% of GDP. Highest correlation that is 0.73 is of gross savings as \% of GDP, and it can be inferred that housing prices are affected by changes in interest rate, credit flow and also changes in GDP \& per capita income (See Table 3 and Figure 3). Joshi. H. (2006) (RBI) also supported the findings that prices in the sector are sensitive in the long run to interest rate/bank rate changes, credit flow conditions \& also changes in $\mathrm{GDP}^{15}$.

Table 3: House Price Index In Relation To GDP, Per Capita NNI and Gross Savings as \% of GDP.

\begin{tabular}{|l|l|l|l|l|}
\hline Year & House Price Index & Gross Domestic Product & Per Capita NNI & Gross Savings as \% of GDP \\
\hline $2010-11$ & & 19.91806 & 18.22408 & 36.909 \\
\hline $2011-12$ & 23.8 & 14.43265 & 11.39302 & 34.64656 \\
\hline $2012-13$ & 28.1 & 13.82371 & 11.85098 & 33.88171 \\
\hline $2013-14$ & 19.3 & 12.96769 & 11.4612 & 32.11987 \\
\hline $2014-15$ & 27.6 & 10.98888 & 9.516783 & 32.2423 \\
\hline $2015-16$ & 19.8 & 10.45812 & 9.404836 & 31.09424 \\
\hline $2016-17$ & 18.5 & 11.76162 & 10.63693 & 31.34886 \\
\hline $2017-18$ & 17.8 & 11.08804 & 9.92849 & 32.39148 \\
\hline $2018-19$ & 12.6 & 10.95391 & 9.738666 & 30.11359 \\
\hline $\begin{array}{l}\text { Correlation } \\
\text { with HPI }\end{array}$ & & $\mathbf{0 . 4 6 7 8 4 3}$ & $\mathbf{0 . 3 6 8 9 6 3}$ & $\mathbf{0 . 7 3 1 0 5 3}$ \\
\hline
\end{tabular}

Source: RBI "Database on Indian Economy-Real Sector-National Income" (DBIE) portal retrieved from https://dbie.rbi.org.in/DBIE/dbie.rbi? site=statistics $>$ Real Sector $>$ National Income $>$ Annual) (Accessed on 12 march, 2020)

13. RBI (Press Release dated Oct 17, 2018) "All-India House Price Index (HPI) annual growth decreased in Q1:2018-19" (Assistant Advisor: Ajit Prasad) downloaded from https://rbidocs.rbi.org.in/rdocs/PressRelease/PDFs/PR9081D83D86DF8784C0E843DD6A1F829C746.PDF (Accessed on 5 march, 2020).

14. RBI "Database on Indian Economy- Financial Sector: Key rates" retrieved from https://dbie.rbi.org.in/DBIE/dbie.rbi?site=statistics>financial sector>key rates (Accessed on 12 march, 2020).

15. Joshi, H. (2006). Identifying asset price bubbles in the housing market in India: Preliminary evidence. Reserve Bank of India Occasional Papers, 27(1), 73-88. 


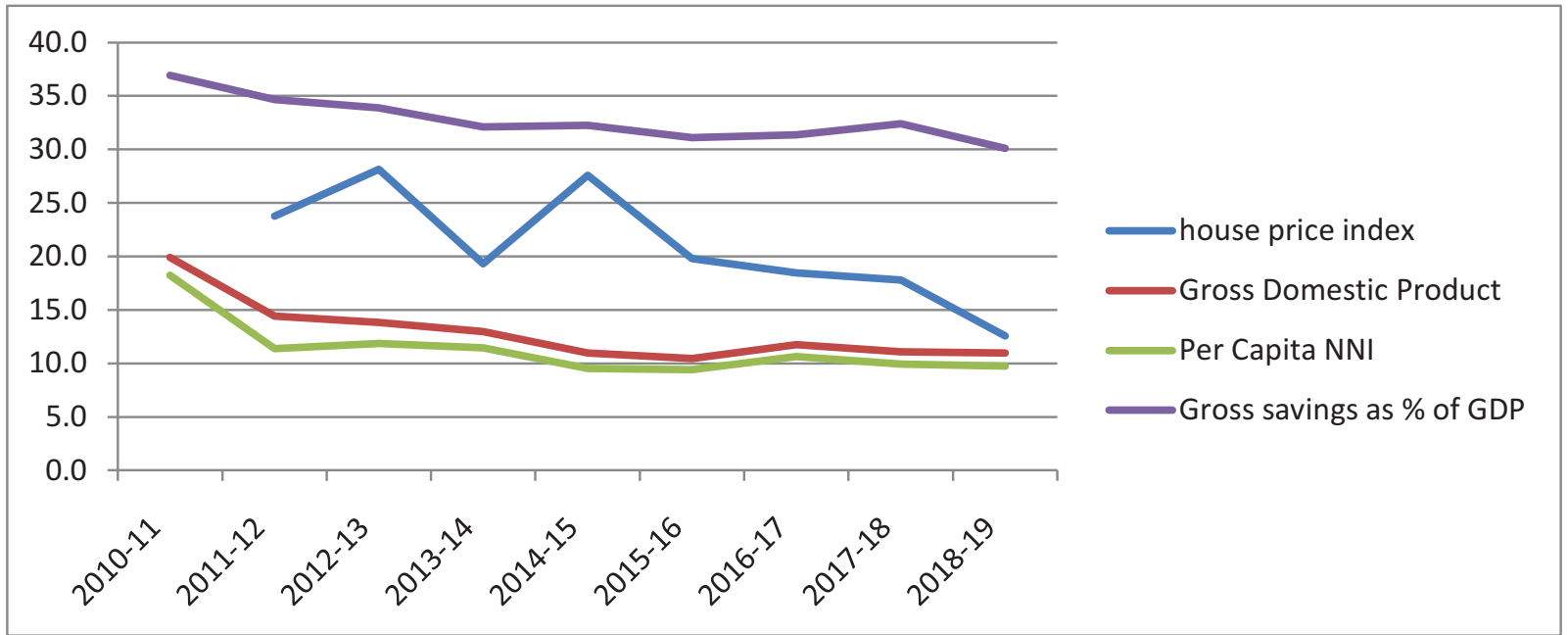

Figure 3: Graph showing Movement of HPI, GDP, Per Capita NNI, Gross Savings as \% of GDP

Source: RBI "Database on Indian Economy-Real Sector-National Income" (DBIE) portal retrieved from https://dbie.rbi.org.in/DBIE/dbie.rbi? site=statistics > Real Sector > National Income > Annual) (Accessed on 12 march, 2020)

We can see that new townships are coming up in metro cities as well as tier II and III cities. Furthermore, attractive tax advantages act as a catalyst in the growth of real estate sector and it encourages salary earners to view the sector as an ideal investment option ${ }^{15}$. The growth in the sector has been supported by various factors such as larger proportion of middle income class; favorable demographic changes such as increase in working population, people are able to live long healthy life thus their earning years increase; growth of job opportunities in the urban mainly metro cities; new business centres being set up in second tier cities such as areas in the vicinity of metro cities(example Delhi-NCR); growth in the information technology \& financial sector and; increase in disposable income of consumers.

\section{CONCLUSION}

Real Estate Sector Investment in India has not been promising for the last many years. Because of stagnant house prices and large number of unsold residential and commercial units, delays in delivery by the builder have made real estate investment lose its shine.

Demonetization brought the real estate sector prices at its real value in India as demonetization hit the black economy badly ${ }^{16}$. Real Estate lost its shine but still we could see some positive changes. Through review of various studies, it can be seen that various economic and non-economic factors affect the real estate investment. Various Studies on boom (explosion) in the sector indicate that improvement in the macro economic conditions cause improvement in the sector, mainly tax incentive \& rate relaxations. Real estate sector picks up when consumers have high disposable incomes which is facilitated by reducing tax liability and improvement in GDP and per capita income levels. The results in the current study indicated that the housing prices were positively affected by reduction in interest rate (rate cuts), larger provision of home loans and

15. Joshi, H. (2006). Identifying asset price bubbles in the housing market in India: Preliminary evidence. Reserve Bank of India Occasional Papers, 27(1), 73-88.

16. Thakur, Pooja (2015, March 19). "Modi's 'Black Money' Crusade Looms Over Property Bubble". Bloomberg News. 19 March 2015. Retrieved 7 July 2015. 
increase in GDP and per capita income. This is what happened in India as well. The Government of India initiated and promoted various favorable steps such as tax incentives, improvement in provisions of home loans which led to the growth of real estate investment. During the last few years; GDP, Per capita NNI have not been growing at promising rates, still the real estate sector has started improving because of various incentives by the Government to support the sector. But unfortunately, the outbreak of pandemic Covid 19 has again hit badly many Economies including Indian Economy. In an article published in Economic times where in the survey of "Knight Frank -FICCI-NAREDCO" was referred to discuss the impact of Covid 19 on the real estate sector in India and the report highlighted that 'the outbreak of ongoing Covid 19 and its detrimental effect on economy have brought sentiment in real estate sector to its lowest level (all time) in Q1 ending March, 2020. New launches, sales and prices are expected to be hit badly in both residential and commercial real estate sectors ${ }^{17818}$. Now we can only hope that it is temporary phase and that war over Covid 19 is won at the earliest.

\section{REFERENCES}

Abraham, J. M., \& Hendershott, P. H. (1994). Bubbles in metropolitan housing markets (No. w4774). National Bureau of Economic Research.

Brown, G., \& Chau, K. (1997). Excess returns in the Hong Kong commercial real estate market. Journal of Real Estate Research, 14(2), 91-105.

Case, K. E., \& Shiller, R. J. (1988). The behavior of home buyers in boom and post-boom markets (No. w2748). National Bureau of Economic Research. Also available at https: //papers.ssrn.com/sol3/papers.cfm?abstract_id
$=421767$ (Retrieved 12 February, 2020)

Case, K. E., \& Shiller, R. J. (2003). Is there a bubble in the housing market? Brookings papers on economic activity, 2003(2), 299-362.

Clayton, J. (1997). Are housing price cycles driven by irrational expectations?. The Journal of Real Estate Finance and Economics, 14(3), 341-363.

Firstenberg, P. M., Ross, S. A., \& Zisler, R. C. (1988). Real estate: the whole story. Journal of Portfolio Management, 14(3), 22. Downloaded from https://search.proquest.com/openview/5e48a4 06578 d 9273925 a 6cc9896c41c0/1?pqorigsite $=$ gscholar\&cbl $=49137$ (Retrieved 10 January, 2020)

Gou, G. (1984). Weak Form tests of efficiency of real estate investments markets. The Financial Review, 19(4), 301-20.

Herring, R., \& Wachter, S. (2003). Bubbles in real estate markets. Asset Price Bubbles: The Implications for Monetary, Regulatory, and International Policies, 217(6), 217-230.

India Brand Equity Foundation (2019) 'Indian Real Estate- Industry Analysis' downloaded from https://www.ibef.org/archives/industry/india n-real-estate-industry-analysis-reports/indianreal-estate-industry-analysis-january-2020 (retrieved 10 March 2020).

India Brand Equity Foundation (2019) 'Real Estate' https://www.ibef.org/download/Real-EstateDecember-2019.pdf (retrieved 10 March 2020).

India Ratings and Research (2019) "Mid-Year FY20 Real Estate Outlook: Liquidity Remains Key for Survival and Growth" from https://www.indiaratings.co.in/PressRelease?p ressReleaseID=38960\&title=Mid-Year-FY20-RealEstate-Outlook\%3A-Liquidity-Remains-Key-forSurvival-and-Growth((Accessed on 10 February, 2020).

17. Babar, Kailash (2020, April 16) "Covid-19 impact: Real estate sentiments hit lowest level" available at :https://economictimes.indiatimes.com/wealth/real-estate/covid-19-impact-real-estate-sentiments-hit-lowestlevel/articleshow/75175857.cms? utm_source=contentofinterestEutm_medium $=$ textEutm_campaign $=$ cppst $($ Retrieved 20April 2020).

18. Knight Frank-FICCI-NAREDCO ( 2020) Real Estate Sentiment Index Q1 2020 - Indian Real Estate Residential E Office downloaded from https://www.knightfrank.co.in/research/real-estate-sentiment-index-q1-2020-indian-real-estateresidential-office-7103.aspx?search-id=aafb6799-81af-475e-bd16-37a1b6fa771fEreport-id=1955Erank=1(Retreived 20 April 2020). 
Joshi, H. (2006). Identifying asset price bubbles in the housing market in India: Preliminary evidence. Reserve Bank of India Occasional Papers, 27(1), 73-88.

Kishore, R. (2004). Theory of behavioural finance and its application to property market: a change in paradigm. Australian Property Journal, 38(2), 105.

Levin, E. J., \& Wright, R. E. (1997). The impact of speculation on house prices in the United Kingdom. Economic modelling, 14(4), 567-585.

Mishra, A. (2018). Gold Investment vs. Real Estate Investment: An Analysis. Journal of Business Management \& Quality Assurance (e ISSN 24569291), 2(1), 33-39. Available at: $<$ http://management.nrjp.co.in/index.php/JBM QA/article/view/184>. (Date accessed: 10 January, 2020).

Pandey, R., \& Jessica, V. M. (2018). Measuring behavioural biases affecting real estate investment decisions in India: using IRT. International Journal of Housing Markets and Analysis. 11(4), 648-668. https://doi.org/10.1108 /IJHMA-12-2017-0103

Pandey, R., \& Jessica, V. M. (2019). Sub-optimal behavioural biases and decision theory in real estate. International Journal of Housing Markets and Analysis.

Pandey, R., \& Jessica, V. M. (2019). Determinants of Indian housing market: Effects and countereffects. Property Management.

Qin, X. (2005). Property market bubbles: some evidence from Seoul and Hong Kong. Nanyang Technological University of Singapore. PhD thesis, Chapter IV.

RBI (2010). Identifying Asset Price Bubbles in the Housing Market in India - Preliminary Evidence" (PDF) Occasional Papers RBI retrieved from https://rbidocs.rbi.org.in/rdocs/publications/p dfs/73533.pdf (7 December 2019).

RBI (Press Release dated Oct 17, 2018) “All-India House Price Index (HPI) annual growth decreased in Q1:2018-19" (Assistant Advisor: Ajit Prasad) downloaded from https://rbidocs.rbi.org.in/rdocs/
PressRelease/PDFs/PR9081D83D86DF8784C0E8 43DD6A1F829C746.PDF (Accessed on 5 march, 2020).

Sahni, M. S., Bank, A. A., \& Point, N. (2008). Real estate sector-the India story. The 14th Annual Conference of the Pacific Rim Real Estate Society.[Online],[Retrieved April 8, 2010] Pacific Rim Real Estate Society. http://www. prres. net/papers/Sonia\% 20_Real_Estate_Sector_The_ India_Story. pdf.

Van Norden S. and Schaller, H. (1993). The Predictability of Stock Market Regime: Evidence from the Toronto Stock Exchange. The Review of Economics and Statistics, 75(3), 505-510.

Van Norden, S. (1996). Regime switching as a test for exchange rate bubbles. Journal of Applied Econometrics, 11(3), 219-251.

Van Norden, S., \& Schaller, H. (1999). Speculative behavior, regime-switching, and stock market crashes. In Nonlinear Time Series Analysis of Economic and Financial Data (pp. 321-356). Springer, Boston, MA.

Vishwakarma, V. K., \& Paskelian, O. G. (2012). Bubble in the Indian real estate markets: Identification using regime-switching methodology. The International Journal of Business and Finance Research, 6(3), 27-40.

Waweru, N.M.,Mwangi, G.G. and Parkinson, J.M. (2014) 'Behavioural factors influencing investment decisions in the Kenyan property market', Afro-Asian J. Finance and Accounting, Vol. 4, No. 1, pp.26-49. Downloaded from https://www.researchgate.net/publication/264 815224_Behavioural_factors_influencing_invest ment_decisions_in_the_Kenyan_property_marke $\mathrm{t}$ (Retrieved 10 February, 2020)

\section{Government Sources}

National Housing Bank- 'Urban Housing under five year plans'. Retrieved from https:/ / test.nhb.org.in/Urban_Housing/5year_ plan.php (Accessed on 10 March, 2020).

RBI "Database on Indian Economy-Time series data on All-India and city-wise HPI" (DBIE) portal 
retrieved

from

https:/ / dbie.rbi.org.in/DBIE/dbie.rbi?site=stati

stics $>$ RealSector $>$ Price\&Wages $>$ Quarterly)

(Accessed on 01 march, 2020).

RBI “Database on Indian Economy- Financial Sector: Key rates" retrieved from https://dbie.rbi.org.in/DBIE/dbie.rbi?site=stati stics $>$ financial sector $>$ key rates (Accessed on 12 march, 2020).

RBI "Database on Indian Economy-Real SectorNational Income" (DBIE) portal retrieved from https:/ / dbie.rbi.org.in/DBIE/dbie.rbi?site=stati stics $>$ Real Sector $>$ National Income $>$ Annual) (Accessed on 12 march, 2020).

\section{Other Internet Sources}

Wikipedia Source "Real Estate Investing" from https://en.wikipedia.org/wiki/Real_estate_inve sting (retrieved 10 March 2020).

Murdock Edgar, Christy. "The 5 Pros and 3 Cons of Real Estate Investing". https:// learn.roofstock.com/blog/pros-andcons-real-estate-investing Accessed from: https://en.wikipedia.org/wiki/Real_estate_inve sting (retrieved 10 March 2020).

\section{Other Sources}

FDI in construction industry (2005,March 12) The Times of India. Retrieved From https:// timesofindia.indiatimes.com/hyderabad / F D I - i n - c o n s t r u c t i o n industry/articleshow/1049608.cms (Retrieved 5 January, 2020).

Tanvir A Siddiqui (2013, October, 11). RBI cautions co-op banks against lump-sum disbursal of loans to builders. The Indian Express from http://archive.indianexpress.com/news/rbicautions-coop-banks-against-lump-sumdisbursal-of-loans-to-builders/1181230/ (Retrieved 5 July 2015).

Thakur, Pooja (2015, March 19). Modi's 'Black Money' Crusade Looms over Property Bubble. Bloomberg

News.

From
https://www.livemint.com/Politics/Rtv0yt2Mu 0ipf6rFJ8m9fO/Narendra-Modis-black-moneycrusade-looms-over-India-propert.html (Retrieved 5 January, 2020).

RERA-All about It. (2016) From http:/ / indianrealestatemarket.com/real-estateregulation-and-development-act-rera-all-aboutit/ (Retrieved 05 March, 2020).

Asit Ranjan M. \& , Shaswati Das (2019,November 6) Cabinet clears ?25,000 crore plan for realty revival The Live Mint Retrieved from https://www.livemint.com/news/india/govtapproves-rs-10-000-crore-fund-to-help-stalledh o u sing - p r o je c t s - s i th a r a m a n 11573051698810.html (Accessed on 10 Feb, 2020).

MG Arun (2020, January 28). Rebuilding Real Estate. India Today Insight, from https://www.indiatoday.in/india-todayinsight/ story / rebuilding-real-estate-16408362020-01-28 (Retrieved 10 February, 2020).

Sharma, Ankit (2020, February 1) What Indian real estate gained in Budget 2020? The Economic Times Retrieved from https://realty.economictimes.indiatimes.com/n ews/industry/what-indian-real-estate-gainedin-budget-2020/73838367 (Accessed on 15 March, 2020).

Babar, Kailash (2020, February 13). India Ratings maintains negative outlook on real estate for FY21, The Economic Times from https://economictimes.indiatimes.com/industry /services/property-/-cstruction/india-ratingsmaintains-negative-outlook-on-real-estate-forfy21/articleshow $/ 74120863 . c m s$ ?utm_source $=$ co ntentofinterest\&utm_medium=text\&utm_campa ign=cppst (Retrieved 2 March, 2020).

Babar, Kailash (2020, April 16) "Covid-19 impact: Real estate sentiments hit lowest level" available at : https://economictimes.indiatimes.com/ wealth/real-estate/covid-19-impact-real-estate$\mathrm{s}$ e $\mathrm{n} \mathrm{t} \mathrm{im}$ e $\mathrm{nt} \mathrm{s}-\mathrm{h} \mathrm{i} \mathrm{t}-1$ o w e s $\mathrm{t}$ level/articleshow $/ 75175857 . c m s ? u t m \_s o u r c e=c 0$ ntentofinterest\&utm_medium =text\&utm_campa ign=cppst (Retrieved 20 April 2020).

Knight Frank-FICCI-NAREDCO ( 2020) Real Estate 
Sentiment Index Q1 2020 - Indian Real Estate Residential \& Office downloaded from https://www.knightfrank.co.in/research/realestate-sentiment-index-q1-2020-indian-realestate-residential-office-7103.aspx?search$\mathrm{i} d=\mathrm{a}$ a f b $6799-81$ a f - $475 \mathrm{e}-\mathrm{bd} 16$ 37a1b6fa771f\&report-id=1955\&rank=1(Retreived 20 April 2020) 